\title{
Stroke Reperfusion Therapy Following Dabigatran Reversal With Idarucizumab in a National Cohort
}

Neurology ${ }^{\circledR} 2021 ; 96: 828$. doi:10.1212/WNL.0000000000009542

In the article "Stroke Reperfusion Therapy Following Dabigatran Reversal With Idarucizumab in a National Cohort" by Barber et al., the first sentence in the Methods section should denote this study as providing Class III evidence. The authors regret the error.

\section{Reference}

1. Barber PA, Wu TY, Ranta A. Stroke reperfusion therapy following dabigatran reversal with idarucizumab in a national cohort. Neurology 2020;94:e1968-e1972.

\section{Leisure Activity Participation and Risk of Dementia}

An 18-Year Follow-up of the Whitehall II Study

Neurology ${ }^{\circledR} 2021 ; 96: 828$. doi:10.1212/WNL.00000000000011447

In the article "Leisure Activity Participation and Risk of Dementia: An 18-Year Follow-up of the Whitehall II Study" by Sommerlad et al., ${ }^{1}$ the second sentence of the Results section should read "During 147,774 person-years at risk, 360 incident dementia cases were recorded (incidence 2.4 per 1,000 person-years)." The short version of the article, published October 28 , 2020, should also have stated "incidence 2.4 per 1,000 person-years." The authors regret the error.

\section{Reference}

1. Sommerlad A, Sabia S, Livingston G, et al. Leisure activity participation and risk of dementia: an 18-year follow-up of the Whitehall II Study. Neurology 2020;95:e2803-e2815.

\section{RETRACTION}

\section{An Alternative to Vitamin D Supplementation to Prevent Fractures in Patients With MS}

Neurology ${ }^{\circledR} 2021 ; 96: 828$. doi:10.1212/WNL.0000000000011856

The Editors retract the article "An Alternative to Vitamin D Supplementation to Prevent Fractures in Patients With MS."1 We previously published an Expression of Concern ${ }^{2}$ about this Letter to the Editor along with several other articles by Y. Sato and others. Since then, the other articles in the Expression of Concern have been retracted.

The Letter to the Editor is strongly reliant on several of its references also authored by Y. Sato. We have learned that references $2,4,5,6$, and 7 in the Letter have been retracted by other journals and therefore retract this Letter.

\section{References}

1. Sato Y, Kaji M, Oizomi K. An alternative to vitamin D supplementation to prevent fractures in patients with MS. Neurology 1999;53:437.

2. Does compensatory hyperparathyroidism predispose to ischemic stroke? Decreased bone mass and increased bone turnover with valproate therapy in adults with epilepsy; An alternative to vitamin D supplementation to prevent fractures in patients with MS; High prevalence of vitamin D deficiency and reduced bone mass in Parkinson's disease [Expression of Concern]. Neurology 2018;90:627. 


\section{Neurology"}

Leisure Activity Participation and Risk of Dementia: An 18-Year Follow-up of the Whitehall II Study Neurology 2021;96;828 Published Online before print January 11, 2021

DOI 10.1212/WNL.0000000000011447

This information is current as of January 11, 2021

Updated Information \&

Services

References

Permissions \& Licensing

Reprints including high resolution figures, can be found at:

http://n.neurology.org/content/96/17/828.2.full

This article cites 1 articles, 1 of which you can access for free at: http://n.neurology.org/content/96/17/828.2.full\#ref-list-1

Information about reproducing this article in parts (figures,tables) or in its entirety can be found online at:

http://www.neurology.org/about/about_the_journal\#permissions

Information about ordering reprints can be found online:

http://n.neurology.org/subscribers/advertise

Neurology ${ }^{\circledR}$ is the official journal of the American Academy of Neurology. Published continuously since 1951, it is now a weekly with 48 issues per year. Copyright (C) 2021 American Academy of Neurology. All rights reserved. Print ISSN:

0028-3878. Online ISSN: 1526-632X

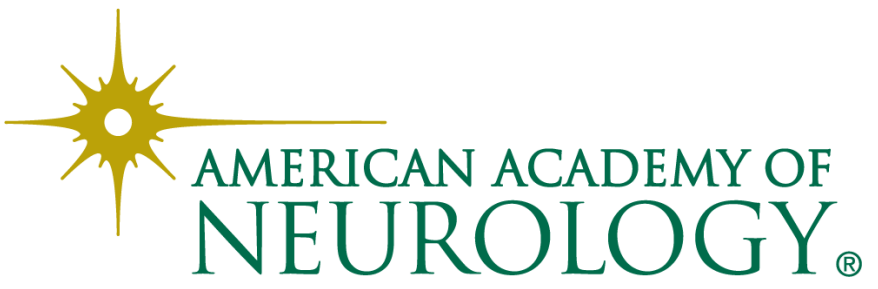

